\title{
PENGARUH MODEL PEMBELAJARAN KOOPERTIF PAIR CHECKS TERHADAP KEMAMPUAN MENYIMPULKAN ISI BERITA PADA SISWA KELAS VIII SMP NEGERI 10 SINGKAWANG
}

\author{
Ira Satira ${ }^{1}$, Eti Sunarsih ${ }^{2}$, Zulfahita $^{3}$ \\ STKIP Singkawang, Singkawang, Indonesia \\ Irasatira08@gmail.com,etisunarsih89@gmail.com,zulfahita@yahoo.co.id.
}

\author{
Keywords : \\ Kooperatif Pair Checks, \\ Menyimpulkan Isi Berita
}

\begin{abstract}
Penelitian ini bertujuan untuk mengetahui ketuntasan hasil belajar siswa mencapai KKM (70) baik secara individual maupun klasikal terhadap kemampuan menyimpulkan isi berita, dan mengetahui hasil belajar siswa sesudah diterapkanya model pembelajaran kooperatif pair checks terhadap kemampuan menyimpulkan isi berita pada siswa kelas VIII SMP Negeri 10 Singkawang lebih baik dibandingkan hasil belajar siswa sebelum diterapkanya model pembelajaran. Penelitian ini merupakan penelitian Pre-Experimental Designs. Dengan menggunakan bentuk "one group pretest-posttest design". Menurut metodeny merupakan jenis penelitian kuantitatif. Populasi dalam penelitian ini adalah semua siswa kelas VIII SMP Negeri 10 Singkawang. Pengambilan sampel dalam penelitian ini menggunakan sampel purposive sampling sebanyak 1 kelas. Teknik pengumpulan data menggunakan tes. Hasil penelitian menunjukkan 1) kemampuan menyimpulkan isi berita mencapai ketuntasan individu dan klasikal yaitu Karena $t_{\text {hitung }}>t_{\text {tabel }}$ atau 6,24 $>1,70$ bahwa rata-rata mencapai $K K M \geq 70$, selanjutnya untuk ketuntasan klasikal yaitu $Z_{\text {hitung }} \geq Z_{\text {tabel }}$ atau $2,25 \geq 1,64$ disimpulkan bahwa ketuntasan klasikal siswa mencapai 75\%. 2) hasil belajar siswa sesudah diterapkanya model pembelajaran kooperatif pair checks terhadap kemampuan menyimpulkan isi berita pada siswa kelas VIII SMP Negeri 10 Singkawang lebih baik dibandingkan hasil belajar siswa sebelum diterapkanya model pembelajaran yaitu $t$ hitung $>$ dari $t_{\text {tabel }}$ yakni - 10,92 > 1,706 disimpulkan bahwa Hasil belajar siswa sesudah diterapkan model pembelajaran kooperatif pair checks terhadap kemampuan menyimpulkan isi berita lebih baik.
\end{abstract}




\section{PENDAHULUAN}

Menulis merupakan suatu kegiatan yang produktif dan ekspresif. Keterampilan menulis merupakan kemampuan mengungkapkan gagasan, pendapat, dan perasaan kepada pihak lain melalui bahasa tulis. Pengungkapan gagasan juga didukung dengan ketepatan bahasa yang digunakan dalam keterampilan menulis adalah menurunkan atau melukiskan lambang-lambang grafik yang menggambarkan suatu bahasa yang dipahami oleh seseorang, sehingga orang lain dapat membaca lambang-lambang grafik tersebut mereka memahami bahasa dan gambaran grafik itu (Tarigan, 2008:22). Dengan keterampilan menulis, siswa dapat mengungkapkan gagasan, pikiran, dan perasaannya dengan terbuka, sehingga siswa dapat mengungkapkan perasaan dan ide pemikirannya secara tidak langsung melalui kegiatan menulis, seperti menulis sebuah berita.

Menulis teks berita merupakan satu di antara kompetensi yang harus dikuasai oleh siswa. Sejalan dengan kurikulum 2013 terdapat pada Kompetensi Inti 4 yang berbunyi: Mencoba, mengolah, dan menyaji dalam ranah konkret (menggunakan, mengurai, merangkai, memodifikasi, dan mem-buat) dan ranah abstrak (menulis, membaca, menghitung, menggambar, dan mengarang) sesuai dengan yang dipelajari di sekolah dan sumber lain yang sama dalam sudut pandang/teori. Melalui Kompetensi Dasar 4.1 yang berbunyi: Menyimpulkan isi berita (membanggakan dan memotivasi) yang dibaca dan didengar.

Berdasarkan tes awal dilakukan yang bertujuan untuk mengetahui nilai kelas yang paling rendah dalam keterampilan menulis untuk menyimpulkan isi berita. Ternyata dari ke lima kelas yaitu VIII A, VIII B, VIII C, VIII D, VIII E dengan persentase ketuntasan sebagai berikut, kelas VIII A 64,28\%, VIII B 46,42\%, VIII C 51,72\%, VIII D 72,41\% dan kelas VIII E 71,42\% dengan nilai KKM 70. Berdasarkan persentase ketuntasan ternyata dari lima kelas yang paling rendah persentase ketuntasannya adalah kelas VIII B. Berdasarkan hasil informasi yang telah dihimpun peneliti dengan guru bahasa Indonesia menyatakan bahwa kemampuan menulis siswa masih rendah itu dikarenakan beberapa hal. Pertama, dalam mengikuti proses pembelajaran siswa kurang serius. Kedua, kemampuan siswa dalam menulis kurang dikarenakan siswa sulit mengembangkan ide pikiran mereka. Ketiga, penggunaan media atau model pembelajaran masih belum maksimal dan kurang bervariasi sehingga siswa kurang termotivasi dalam mengikuti proses pembelajaran. Permasalahan tersebutlah yang melatar belakangi peneliti sehingga berkeinginan untuk melakukan penelitian di kelas VIII B untuk meningkatkan kemampuan siswa dalam menulis khususnya menyimpulkan isi berita dan meningkatkan nilai siswa menjadi lebih baik lagi. Dalam melaksanakan penelitian ini peneliti bekerjasama dengan guru bahasa Indonesia di sekolah SMP Negeri 10 Singkawang. Satu di antara model yang dapat digunakan untuk mengatasi masalah ini ialah dengan menggunakan model kooperatif pair checks. Penelitian ini merumuskan tiga permasalahan. (1) Apakah ketuntasan hasil belajar siswa mencapai (KKM 70) baik secara individual maupun klasikal terhadap kemampuan menyimpulkan isi berita pada siswa kelas VIII SMP Negeri 10 Singkawang?, (2) Apakah hasil belajar siswa sesudah diterapkanya model pembelajaran kooperatif pair checks terhadap kemampuan menyimpulkan isi berita pada siswa kelas VIII SMP Negeri 10 Singkawang lebih baik dibandingkan hasil belajar siswa sebelum diterapkanya model pembelajaran? Berdasarkan rumusan masalah tersebut, penelitian ini bertujuan untuk, (1) Untuk mengetahui ketuntasan hasil belajar siswa mencapai KKM (70) baik secara individual maupun klasikal terhadap kemampuan menyimpulkan isi berita pada siswa kelas VIII SMP Negeri 10 Singkawang, (2) Untuk mengetahui hasil belajar siswa sesudah diterapkanya model pembelajaran kooperatif pair checks terhadap kemampuan menyimpulkan isi berita pada siswa kelas VIII SMP Negeri 10 Singkawang lebih baik dibandingkan hasil belajar siswa sebelum diterapkanya model pembelajaran.

Teks berita merupakan teks yang menuntut ketelitian pemahaman, kekiritisan berpikir serta keterampilan dalam mengembangkan sebuah berita yang dapat memberikan informasi penting kepada 
khalayak sesuai fakta. Berita adalah sebuah informasi yang penting dan menarik perhatian serta minat khalayak pendengar, yang berupa laporan tentang fakta atau ide yang termasa. Dipilih oleh staf redaksi suatu harian untuk disiarkan, yang menarik perhatian pembaca, dengan alasan karena berita yang disiarkan itu luar biasa atau karena berita yang disiarkan itu sangat penting. Berita selalu mencakup segi-segi seperti humor, emosi, dan ketegangan. Berita juga merupakan ide terbaru yang benar, menarik dan atau penting bagi sebagian besar khalayak. Melalui media berkala seperti surat kabar, radio, televisi atau media internet (Sumadaria, 2005:64). Sehingga berita dapat memberikan informasi penting dan terbaru kepada khalayak ramai sesuai fakta.Djuraid (2012:9) menyatakan Berita adalah sebuah laporan atau pemberitahuan mengenai terjadinya sebuah peristiwa atau keadaan yang bersifat umum dan baru saja terjadi yang disampaikan oleh wartawan di media massa. Peristiwa atau keadaan yang disampaikan tersebut merupakan fakta atau benar-benar terjadi. Dengan kata lain, berita sama sekali tidak boleh mengandung unsur rekaan atau fiksi dari penulis.

Satu di antara model yang dapat digunakan untuk mengatasi masalah ini ialah dengan menggunakan model kooperatif pair checks. Pair checks merupakan metode pembelajaran berkelompok antar dua orang atau berpasangan yang dipopulerkan oleh Spencer Kagan pada 1990. Model ini menerapkan pembelajaran kooperatif yang menuntut kemandirian dan kemampuan siswa dalam menyelesaikan persoalan. Metode ini juga melatih tanggung jawab sosial siswa, kerja sama, dan kemampuan memberi penilaian. Menurut Herdian (dalam Shoimin 2013:119) model pair checks (pasangan mengecek) merupakan model pembelajaran di mana siswa saling berpasangan dan menyelesaikan persoalan yang diberikan. Dalam model pembelajaran kooperatif tipe pair checks, guru bertindak sebagai motivator dan fasilitator aktivitas siswa. Model pembelajaran ini juga untuk melatih rasa sosial siswa, kerja sama, dan kemampuan memberi penilaian. Model ini bertujuan untuk meningkatkan kemampuan siswa dalam menuangkan ide, pikiran, pengalaman, dan pendapatnya dengan benar. Dengan model pair check memungkinkan bagi siswa untuk saling bertukar pendapat dan saling memberikan saran.

Istarani \& Ridwan (2015:165) menyatakan bahwa. Pair checks ialah suatu cara penyampaian materi ajar dengan membentuk kelompok dalam sebangku, di mana antara mereka saling mengajukan pertanyaan dan saling menjawab pertanyaan, yang kemudian saling mengecek kebenaran jawaban dari pertanyaan yang dilontarkannya. Kemudian mereka mengambil kesimpulan dan baru pada akhirnya guru melakukan evaluasi dan refeksi pembelajaran.

Dari pendapat di atas maka dapat disimpulkan bahwa model pembelajaran pair checks adalah belajar kelompok antara dua orang atau berpasangan, salah seorang menyajikan pertanyaan atau persoalan dan temannya melakukan pengecekan kebenaran jawaban, bertukar peran, menyimpulkan, dan evaluasi, refleksi. Model ini menuntut kemandirian dan kemampuan siswa dalam menyelesaikan persoalan.

\section{METODE}

Penelitian yang digunakan dalam penelitian ini adalah penelitian kuantitatif dengan metode eksperimen karena data yang diperoleh berhubungan dengan angka-angka yang dapat dihitung secara sistematis. Menurut (Sugiyono, 2016:107) "Metode penelitian eksperimen dapat di artikan sebagai metode penelitian yang digunakan untuk mencari pengaruh perlakuan terhadap yang lain dalam kondisi yang terkendali". Bentuk penelitian yang digunakan dalam penelitian ini adalah dengan preexperimental design (nondesigns) dikatakan Pre-experimental Designs, karena desain ini belum merupakan eksperimen sungguh-sungguh. Masih terdapat variabel luar yang ikut berpengaruh terhadap terbentuknya variabel dependen. Rancangan ini berguna untuk mendapatkan informasi awal terhadap pertanyaan yang ada dalam penelitian. Jadi hasil eksperimen yang merupakan variabel dependen itu bukan semata-mata dipengaruhi oleh variabel independen. Hal ini terjadi, karena tidak adanya variabel kontrol, dan sampel tidak dipilih secara random.

Penelitian ini hanya menggunakan pada satu kelompok sampel, siswa yang diberikan tes awal (pretest) kemudian siswa diberi perlakuan tertentu. Setelah itu dilakukan pengukuran hasil siswa 
tersebut dengan memberikan tes akhir (posttest). Pada peneltian ini digunakan rancangan one-group pretest-posttest design. Sugiyono (2015:74) menerangkan rancangan penelitian dengan one-group pretest-posttest design. Hasil perlakuan dapat diketahui lebih akurat, karena dapat membandingkan dengan keadaan sebelum diberi perlakuan.

Populasi adalah adalah wilayah generalisasi yang terdiri atas: obyek/subyek yang mempunyai kualitas dan karakteristik tertentu yang ditetapkan oleh peneliti untuk dipelajari dan kemudian ditarik kesimpulanya. Arikunto (2010:173) menyatakan "Populasi adalah keseluruhan subjek penelitian".sedangkan menurut Sugiyono (2016:117) menyatakan "Populasi adalah adalah wilayah generalisasi yang terdiri atas: obyek/subyek yang mempunyai kualitas dan karakteristik tertentu yang ditetapkan oleh peneliti untuk dipelajari dan kemudian ditarik kesimpulanya". Populasi dalam penelitian ini adalah seluruh siswa kelas VIII SMP Negeri 10 Singkawang yang berjumlah 142 orang yang terdiri dari 5 (lima) kelas, yaitu VIII A, VIII B, VIII C, VIII D, VIII E.

Sampel adalah sebagian populasi yang menjadi sumber data dalam penelitian. Sugiyono (2016:118) menyatakan "Sampel adalah bagian dari jumlah dan karakteristik yang dimiliki populasi tersebut". Sampel adalah sebagian atau wakil populasi yang diteliti (Arikunto, 2010:174). penelitian ini menggunakan nonprobability sampling. Sugiyono (2015:84) Nonprobability sampling adalah teknik pengambilan sampel yang tidak memberi peluang/ kesempatan sama bagi setiap unsur atau anggota populasi untuk dipilih menjadi sampel. Adapun jenis nonprobability sampling yang dipilih adalah purposive sampling. Arikunto (2010:183) menyatakan " Sampling purposive dilakukan dengan cara mengambil subjek bukan didasarkan random. . Tetapi, didasarkan atas tujuan tertentu. , sampel dalam penelitian ini dari 5 kelas yang berjumlah 142 orang, maka yang dijadikan sampel hanya satu kelas yaitu VIII B dengan jumlah siswa 28 orang.

Teknik pengumpulan data adalah cara-cara yang dapat digunakan oleh penulis untuk mengumpulkan data. Data yang diperoleh melalui kegiatan penelitian merupakan faktor yang sangat penting dalam memecahkan masalah dalam penelitian. Adapun dalam penelitian ini teknik pengumpulan data yang digunakan teknik pengukuran, dan teknik observasi langsung. Teknik yang digunakan dalam penelitian ini adalah teknik pengukuran. Teknik analisis data dapat diartikan sebagai upaya mengolah data menjadi informasi, sehingga karakteristik atau sifat-sifat data tersebut dapat dengan mudah dipahami dan bermanfaat untuk menjawab masalah-masalah yang berkaitan dengan kegiatan penelitian. Maka dari itu, teknik analisis data sangatlah penting untuk dilakukan dalam proses penelitian. Sebab, dari analisis yang dilakukan peneliti dapat mengambil kesimpulan atas apa yang telah dilakukan. Menurut Bogdan (dalam Sugiyono, 2016:334) Analisis data adalah proses mencari dan menyusun secara sistematis data yang diperoleh dari hasil wawancara, catatan lapangan, dan bahan-bahan lain, sehingga mudah dipahami, dan temuanya dapat diinformasikan kepada orang lain.

\section{HASIL DAN PEMBAHASAN}

Hasil penelitian diperoleh berupa kumpulan data berdasarkan penelitian yang telah dilaksanakan. Adapun data yang diperoleh dalam penelitian ini yaitu.

1. Ketuntasan hasil belajar siswa mencapai KKM (70) baik secara individual maupun klasikal terhadap kemampuan menyimpulkan isi berita pada siswa kelas VIII SMP Negeri 10 Singkawang.

Ketuntasan merupakan ketercapaian hasil belajar siswa yang diperoleh dari nilai pre-test dan post-test SMP Negeri 10 Singkawang dengan rata-rata KKM $=70$. Untuk memperoleh hasil kesimpulan dan untuk mengukur ketuntasan individual dan klasikal terhadap kemampuan menyimpulkan isi berita pada siswa kelas VIII B SMP Negeri 10 Singkawang sebelum pre-test setelah (post-test) proses pembelajaran.

1) Ketuntasan Belajar Individual

Ketuntasan individual adalah setiap siswa dikatakan tuntas belajarnya jika siswa mencapai KKM $=70$.

Hipotesis untuk menentukan ketuntasan belajar individual yaitu. 
$\mathrm{H}_{\mathrm{o}}: \mu<70$ ( Rata-rata kemampuan menyimpulkan isi berita siswa kurang dari 70 berarti belum mencapai KKM yaitu 70).

$\mathrm{H}_{\mathrm{a}}: \mu \geq 70$ ( Rata-rata kemampuan menyimpulkan isi berita siswa lebih dari 70 berarti mencapai KKM yaitu 70).

Berdasarkan data nilai rata-rata pre-test dan post-test untuk ketuntasan individual sebelum (pre-test) dan sesudah (post-test) menggunakan model pembelajaran kooperatif pair checks ditampilkan dalam tabel 4.1 Sebagai berikut.

Tabel 4.1 Hasil Tes Pre-test dan Post-test Ketuntasan Belajar Individual

\begin{tabular}{ccccc}
\hline Kelompok & Sampel & Rata-rata & $\mathrm{t}_{\text {hitung }}$ & $\mathrm{t}_{\text {tabel }}$ \\
\hline Pre-test & 28 & 64,89 & $-2,09$ & 1,70 \\
\hline Post-test & 28 & 79,42 & 6,24 & 1,70 \\
\hline
\end{tabular}

Ketuntasan individual pre-test $\mathrm{n}=28$ belum mencapai tuntas, karena sesuai kriteria pengujian hipotesis $\mathrm{H}_{\mathrm{o}}$ ditolak jika $\mathrm{t}_{\text {hitung }} \geq \mathrm{t}_{\text {tabel }}$ jika dalam hal lain $\mathrm{H}_{\mathrm{o}}$ ditolak $\left(\mathrm{H}_{\mathrm{a}}\right.$ diterima). Karena $\mathrm{t}_{\text {hitung }}<\mathrm{t}_{\text {tabel }}$ atau $-2,09<1,70$ maka dapat disimpulkan bahwa rata-rata hasil belajar pre-test belum mencapai KKM yaitu 70 .

Sedangkan hasil pada post-test $\mathrm{n}=28$ sesuai kriteria pengujian $\mathrm{H}_{\mathrm{o}}$ ditolak jika $\mathrm{t}_{\text {hitung }} \geq \mathrm{t}_{\text {tabel }}$ jika dalam hal lain $\mathrm{H}_{\mathrm{o}}$ ditolak $\left(\mathrm{H}_{\mathrm{a}}\right.$ diterima). Karena $\mathrm{t}_{\text {hitung }}>\mathrm{t}_{\text {tabel }}$ atau 6,24 $>1,70$ maka dapat disimpulkan bahwa rata-rata siswa mencapai KKM yaitu 70. Dengan demikian dapat disimpulkan bahwa rata-rata hasil belajar siswa post-test meningkat setelah diberikan perlakuan dengan menggunakan model pembelajaran kooperatif pair checks.

2) Rata-rata ketuntasan Belajar Klasikal

Ketuntasan klasikal suatu kelas dikatakan tuntas belajarnya jika proporsi mendapatkan nilai KKM $\geq$ 70 mencapai $75 \%$. Hipotesis untuk menentukan ketuntasan belajar klasikal yaitu:

$\mathrm{H}_{\mathrm{o}}: \pi<75 \%$ (proporsi siswa mendapatkan nilai $\mathrm{KKM} \geq 70$ belum mencapai $75 \%$ ).

$\mathrm{H}_{\mathrm{a}}: \pi \geq 75 \%$ ( proporsi siswa mendapatkan nilai KKM $\geq 70$ mencapai $75 \%$ ).

Berdasarkan data nilai rata-rata pretest dan post-test untuk ketuntasan klasikal di tampilkan dalam tabel 4.2 sebagai berikut.

Tabel 4.2 Hasil Tes Pretest dan Post-test Ketuntasan Belajar Klasikal

\begin{tabular}{ccccc}
\hline Kelompok & Sampel & Rata-rata & $Z_{\text {hitung }}$ & $Z_{\text {tabel }}$ \\
\hline Pre-test & 28 & 64,89 & -4 & 1,64 \\
\hline Post-test & 28 & 79,42 & 2,25 & 1,64 \\
\hline
\end{tabular}

Ketuntasan klasikal pada tes pre-test sesuai pengujian hipotesis $\mathrm{H}_{\mathrm{o}}$ ditolak jika $\mathrm{Z}_{\text {hitung }} \geq \mathrm{Z}_{\text {tabel }}$ jika dalam hal lain $\mathrm{H}_{\mathrm{o}}$ diterima maka $\mathrm{H}_{\mathrm{a}}$ ditolak. Karena $\mathrm{Z}_{\text {hitung }} \leq \mathrm{Z}_{\text {tabel }}$ atau $-4 \leq 1,64$ disimpulkan bahwa proporsi siswa mendapat nilai KKM $\geq 70$ belum mencapai $75 \%$, berarti untuk pre-test atau sebelum menggunakan model pembelajaran kooperatif Pair Checks ketuntasan klasikal belum mencapai $75 \%$. Sedangkan untuk ketuntasan klasikal post-test 7 sesuai pengujian hipotesis $\mathrm{H}_{\mathrm{o}}$ ditolak jika $\mathrm{Z}_{\text {hitung }} \geq$ $\mathrm{Z}_{\text {tabel }}$ jika dalam hal lain $\mathrm{H}_{\mathrm{o}}$ diterima maka $\mathrm{H}_{\mathrm{a}}$ ditolak. Karena $\mathrm{Z}_{\text {hitung }} \geq \mathrm{Z}_{\text {tabel }}$ atau 2,25 $\geq 1,64$. Disimpulkan bahwa proporsi siswa mendapat nilai KKM $\geq 70$ mencapai $75 \%$. Dapat disimpulkan bahwa post-test setelah menggunakan model pembelajaran kooperatif pair checks ketuntasan klasikal mencapai $75 \%$.

2. Hasil belajar siswa sesudah diterapkanya model pembelajaran kooperatif pair checks terhadap kemampuan menyimpulkan isi berita pada siswa kelas VIII SMP Negeri 10 Singkawang lebih baik dibandingkan hasil belajar siswa sebelum diterapkanya model pembelajaran.

Untuk mengetahui hasil belajar siswa sesudah diterapkan model pembelajaran, maka dilakukan perhitungan dengan menggunakan uji $t$-test berkolerasi uji pihak kanan. 
Journal of Educational Review and Research

Vol. 3 No. 1, July 2020: 45 - 51

e-ISSN: 2597-9760, p-ISSN: 2597-9752

Tabel 4.3Perhitungan Uji t Satu ihak

\begin{tabular}{|c|c|}
\hline $\begin{array}{c}\text { Nilai Pre-test } \\
\left(\mathbf{X}_{\mathrm{i}}\right)\end{array}$ & $\begin{array}{c}\text { Nilai Post-test } \\
\left(\mathrm{Y}_{\mathrm{i}}\right)\end{array}$ \\
\hline 73 & 80 \\
\hline 60 & 73 \\
\hline 66 & 80 \\
\hline 73 & 93 \\
\hline 66 & 73 \\
\hline 73 & 86 \\
\hline 40 & 66 \\
\hline 80 & 86 \\
\hline 60 & 80 \\
\hline 53 & 73 \\
\hline 80 & 93 \\
\hline 73 & 80 \\
\hline 46 & 73 \\
\hline 80 & 86 \\
\hline 66 & 86 \\
\hline 46 & 66 \\
\hline 73 & 73 \\
\hline 86 & 93 \\
\hline 86 & 93 \\
\hline 73 & 73 \\
\hline 60 & 86 \\
\hline 53 & 73 \\
\hline 73 & 80 \\
\hline 66 & 80 \\
\hline 53 & 73 \\
\hline 66 & 80 \\
\hline 60 & 73 \\
\hline 40 & 73 \\
\hline$\sum X 1817$ & 2224 \\
\hline $\bar{x} 64,89$ & $\overline{\bar{X}} 79,42$ \\
\hline $\mathrm{S}_{1} 12,92$ & $\mathrm{~S}_{2} 8,00$ \\
\hline $\begin{array}{ll}\mathrm{S}^{2} & 167,16\end{array}$ & $\begin{array}{ll}\mathrm{S}^{2} & 64,03 \\
\end{array}$ \\
\hline
\end{tabular}

Berdasarkan perhitungan yang telah dilakukan didaptkan harga t hitung sebesar -10,92 kemudian dibandingkan dengan harga $\mathrm{t}_{\text {tabel }}$ dengan $\mathrm{dk} \mathrm{n}-2=26$. Bila dk 26 uji satu pihak dengan taraf kesalahan $5 \%$ maka $\mathrm{t}_{\text {tabel }}=1,706$. Jadi dapat disimpulkan berdasarkan perhitungan $\mathrm{t}_{\text {hitung }}>$ dari $\mathrm{t}$ tabel yakni 10,92 > 1,706 maka dengan itu $\mathrm{H}_{\mathrm{a}}$ diterima dan $\mathrm{H}_{\mathrm{o}}$ ditolak. Dengan demikian dapat disimpulkan bahwa Hasil belajar siswa sesudah diterapkan model pembelajaran kooperatif pair checks terhadap kemampuan menyimpulkan isi berita lebih baik dari kemampuan sebelum diterapkannya model pembelajaran.

\section{KESIMPULAN DAN SARAN}

Berdasarkan hasil penelitian dan pembahasan dapat ditarik kesimpulan "pengaruh model pembelajaran kooperatif pair checks terhadap kemampuan menyimpulkan isi berita pada siswa kelas VIII SMP Negeri 10 Singkawang tahun ajaran 2018/2019" kesimpulan tersebut dapat diuraikan sebagai berikut. 
Ketuntasan hasil belajar siswa secara individual maupun klasikal post-test mencapai KKM 70 setelah diberikan perlakuan dengan menggunakan model kooperatif pair checks terhadap kemampuan menyimpulkan isi berita pada siswa kelas VIII SMP Negeri 10 Singkawang. Dibuktikan dengan hasil perhitungan ketuntasan individu Karena $t_{\text {hitung }}>t_{\text {tabel }}$ atau 6,24 $>1,70$ dan hasil perhitungan ketuntasan klasikal Karena $Z_{\text {hitung }} \geq Z_{\text {tabel }}$ atau $2,25 \geq 1,64$.

Hasil belajar siswa sesudah diterapkan model pembelajaran kooperatif pair checks terhadap kemampuan menyimpulkan isi berita pada siswa kelas VIII SMP Negeri 10 Singkawang tahun ajaran 2018/2019 lebih baik dibandingkan hasil belajar siswa sebelum diterapkanya model pembelajaran. Dibuktikan dengan hasil perhitungan uji $\mathrm{t}$ satu pihak $\mathrm{t}_{\text {hitung }}>$ dari $\mathrm{t}_{\text {tabel }}$ yakni $-10,92>1,706$.

Hasil penelitian ini diharapkan dapat memberikan manfaat dalam pendidikan sebagai usaha meningkatkan kualitas secara umum dalam bidang pendidikan khususnya pendidikan Bahasa Indonesia. Saran yang dapat di diberikan berkaitan dengan hasil penelitian ini adalah sebagai berikut. Model pembelajaran kooperatif pair checks dapat menjadi satu diantara alternatif dalam pembelajaran bahasa Indonesia untuk meningkatkan kemampuan menyimpulkan isi berita. Mengimplementasikan model pembelajaran kooperatif pair checks maka hendaknya menggunakannya sesuai tujuan pendidikan agar dapat meningkatkan hasil, aktivitas, dan dapat meningkatkan prestasi belajar siswa dengan baik dan menerapkan model pembelajaran yang menarik dalam setiap proses belajar mengajar agar mendapatkan hasil optimal. Saat proses pembelajaran hendaknya memberikan arahan yang jelas kepada siswa agar siswa memahami jalannya pembelajaran dengan menggunakan model pembelajaran kooperatif pair checks dan melihat kegiatan siswa selama pembelajaran berlangsung.

\section{DAFTAR PUSTAKA}

Arikunto, Suharsimi. 2010. Prosedur Penelitian Suatu Pendekatan Praktik. Jakarta: Rineka Cipta.

Djuraid, N Husnun. 2012. Panduan Menulis Berita. Malang: Universitas Muhammadiyah Malang. Nawawi, Hadari. 2012. Metode Penelitian Bidang Sosial. Pontianak: Gajah Mada University Press. Nurgiyantoro, Burhan. 2014. Penilaian Pembelajaran Bahasa Berbasis kompetensi. Yogyakarta: BPFE-YOGYAKARTA.

Ridwan, Muhammad,\& Istarani, 2015. 50 Tipe, Strategi dan Teknik Pembelajaran Kooperatif. Medan: Media Persada.

Shoimin, Aris. 2013. 68 Model Pembelajaran Inovatif dalam Kurikulum 2013. Yogyakarta: ARRUZZMEDIA.

Sugiyono. 2015. Metode Penelitian Kuantitatif, Kualitatif Dan R\&D. Bandung: Alfabeta.

Sugiyono. 2016. Metode Penelitian Pendidikan Pendekatan Kuantitatif, Kualitatif, dan $R \& D$. Bandung: Alfabeta.

Sumadiria, Haris. 2005. Jurnalistik Indonesia Menulis Berita Dan Feature: Panduan Praktis Jurnalis Profesional. Bandung: Simbiosa Rekatama Media.

Tarigan, Henry Guntur. 2008. Menulis Sebagai Suatu Keterampilan Berbahasa. Bandung: Angkasa. 